\title{
Coconut Oil: Bringing History, Common Sense and Science Together
}

\author{
Fabian M. Dayrit*
}

Department of Chemistry, School of Science and Engineering, Loyola Schools, Ateneo de Manila University, Katipunan Ave., Loyola Heights, Quezon City 1108

This article was written in response to the advisory published by the American Heart Association (AHA) warning the public against the use of coconut oil due to its saturated fat content (Sacks FM, Lichtenstein AH, Wu JHY, Appel LJ, Creager MA, Kris-Etherton PM, et al. Dietary Fats and Cardiovascular Disease: A Presidential Advisory From the American Heart Association. Circulation. 2017;136(3):e1--e23.).

This article was first published in the websites of the Asian Pacific Coconut Community (www.apccsec.org) and the Integrated Chemists of the Philippines (www.icp.org.ph). Dr. Fabian Dayrit is also the chairman of the Scientific Advisory Committee for Health of the Asian and Pacific Coconut Community and the president of the Integrated Chemists of the Philippines.

\section{ABSTRACT}

The modern Western diet has suffered the damaging effects of trans fats, much of it from soybean oil. It is suffering another blow, this time from the damaging effects of an excess of omega- 6 fats, again from soybean oil.

The vast majority of epidemiological studies do not distinguish between coconut oil and animal fat, and simply refer to them collectively as "saturated fat." This is a fatal mistake for two reasons: first, the fatty acid profiles of coconut oil and animal fat are very different, and second, coconut oil hardly has any cholesterol while animal fats contain a lot of cholesterol. This means that the results based on animal fat cannot be applied to coconut oil.

Contrary to the claim of the AHA, there is abundant evidence to show that coconut oil and a coconut diet do not raise the incidence of heart disease and are, in fact, part of many healthy traditional diets. Many populations who shifted from a traditional coconut diet to a Western diet have suffered worse health outcomes. However, the historical and scientific evidence in support of coconut oil may not be enough to convince the AHA which favors a high omega- 6 diet.

\section{INTRODUCTION}

"Only wholeness leads to clarity."-Schiller

The 2017 AHA Presidential Advisory has failed to see the forest for the trees. It has failed to see the worsening epidemics of obesity and metabolic disease, but has focused instead on the details of the meta-analysis of LDL and $r$ values as if these were more important. The AHA has failed to bring the science together with the reality; there is no wholeness in their analysis.

Food is made up of three principal biochemical 
groups: protein, carbohydrate and fat. Assuming that one needs to maintain a certain level of energy, a food group cannot be decreased without compensation with another group. The "low fat" recommendation promoted by the AHA and the Dietary Guidelines for Americans since 1980 has resulted in an increase in refined carbohydrates: the American average fat consumption dropped from over $40 \%$ to $33 \%$ while carbohydrate consumption increased and obesity more than doubled from $14 \%$ to $36.5 \%$ (CDC, 2017). Worldwide obesity has likewise more than doubled since 1980, and by 2014, 13\% were obese (WHO, 2016). Meanwhile, heart disease, the principal concern of the AHA and the justification of the Dietary Guidelines, has remained as the \#1 cause of mortality.

The AHA and the Dietary Guidelines have led the Americans - and the rest of the world - astray with its warning against fat, especially saturated fat. However, if we go back to the time before the Dietary Guidelines made the world obese, we will find the answer and rediscover what traditional food cultures have been consuming for millennia: the coconut. This essay will show that, contrary to the claims of the AHA, the evidence for coconut oil is based on science and validated by the experience of people.

\section{THE MODERN DIET}

WHO recommends that the total energy from fat should not exceed 30\% along with a shift in fat consumption away from saturated to unsaturated fat and the elimination of industrial trans fats (WHO, 2015). This works out to about 70 grams or about $75 \mathrm{~mL}$ of fat. Since we should aim for a healthy total fat diet, how much of each type of fat should we consume? How much saturated fat is desirable and what type should this be? How much unsaturated fat should one have? How can we eliminate industrial trans fats completely? Since there is a trend to decrease the amount of carbohydrates in the diet how should we replace these calories?

It was the rising popularity of coconut oil that may have prompted the AHA to issue its Presidential Advisory. In its discussion of coconut oil, they said: "A recent survey reported that $72 \%$ of the American public rated coconut oil as a 'healthy food' compared with $37 \%$ of nutritionists. This disconnect between lay and expert opinion can be attributed to the marketing of coconut oil in the popular press." The AHA then issued a warning against coconut oil: "[B] ecause coconut oil increases LDL cholesterol, a cause of CVD, and has no known offsetting favorable effects, we advise against the use of coconut oil" (Sacks et al., 2017).
In addition, the AHA unilaterally disposed of the importance of HDL to cancel the favorable effects of coconut oil, an issue that was tackled in the second article in this series (Dayrit, 2017b). The stated objective of the AHA is to limit the consumption of coconut oil down to $6 \%$. This essay will answer these allegations and show that the claims of the AHA are wrong.

\section{THE TRANS FATS FIASCO}

Coconut oil used to enjoy robust consumption in the US from the 1900s up to 1940 , when the war interrupted the importation of coconut. During the war, trans fats, much of it from soybean oil, were used to replace coconut oil in food products (Shurtleff \& Aoyagi, 2007). After the war, US importation of coconut oil remained low because of the soybean lobby that wanted to retain its market dominance. By 1999, it was estimated that trans fats in the American diet had reached 2.6\% of calories (Allison et al., 1999). In 2006, it was estimated that trans fats may have been responsible for 72,000 to 228,000 myocardial infarctions and deaths from CHD in the US (accounting for 6\% to 19\%) (Mozaffarian et al., 2006).

Over 30 years after the warning against trans fats was first made, the FDA finally set a compromise rule where a manufacturer can declare "zero trans-fats" if the product contains less than 0.5 grams trans fatty acids per serving (FDA, 2003). This ruling actually does not eliminate trans fats from the food supply; it just hides it.

What is equally lamentable is the AHA's tepid warning against trans fats. Despite the substantial harm that industrial trans fats have made to heart health, the AHA has not issued any advisory against trans fats in the same way that it has attacked saturated fat and coconut oil.

\section{THE HIGH OMEGA-6 FIASCO}

Linoleic acid (C18:2) and linolenic acid (C18:3) are both essential fatty acids. However, international nutrition institutions recommend that only a limited amount should be taken and that a particular ratio should be maintained (Table 1).

The American Soybean Association is a very powerful industry lobby (https://soygrowers.com/). Soybean oil is a high omega- 6 oil, being made up of about 54\% C18:2 (Codex, 2015). It was estimated that from 1909 to 1999 the per capita consumption of soybean oil in the US increased over 1,000 times from 0.01 to $11.6 \mathrm{~kg} / \mathrm{yr}$ and by 1999 , the average American consumption of C18:2 was $7.2 \%$ of total 
Table 1. Recommendations for Daily Intake (in grams) of Omega-6 and Omega-3, and Omega-6 to Omega-3 Ratio from International Institutions.

\begin{tabular}{lrrr}
\hline \multirow{2}{*}{ Agency } & $\begin{array}{r}\text { Linoleic acid } \\
(\mathbf{C 1 8 : 2}) \\
\text { Omega-6 }\end{array}$ & $\begin{array}{r}\text { Linolenic acid } \\
(\mathbf{C} 18: 3) \\
\text { Omega-3 }\end{array}$ & $\begin{array}{r}\text { Healthy ratio } \\
\text { Omega-6 : } \\
\text { Omega-3 }\end{array}$ \\
\hline \begin{tabular}{l} 
European \\
Scientific \\
Committee on \\
\cline { 2 - 4 } Food $^{1}$
\end{tabular} & $2 \%$ & $0.5 \%$ & $5: 1$ \\
\hline $\begin{array}{l}\text { European } \\
\text { Food Safety } \\
\text { Authority }\end{array}$ & $6.4 \mathrm{~g}^{* *}$ & $1.6 \mathrm{~g}^{* *}$ & \\
\hline $\begin{array}{l}\text { World Health } \\
\text { Organization }\end{array}$ & $10 \mathrm{~g}$ & $2 \mathrm{~g}$ & $5: 1$ \\
\hline
\end{tabular}

${ }^{1}$ SCF, 1992; ${ }^{2}$ EFSA, 2009; ${ }^{3}$ FAO/WHO, 2008.

* recommendation for women ${ }^{* *}$ recommendation for men

calories, with an omega- 6 to omega-3 ratio of 10:1 (Blasbalg et al., 2011). The modern American diet has become a high omega- 6 fat diet.

In 2009, AHA issued a "Science Advisory" in a paper entitled: "Omega-6 Fatty Acids and Risk for Cardiovascular Disease" (Harris et al., 2009). This paper summarized and defended the health benefits of omega- 6 fatty acids. However, the ASA Science Advisory ignored the important issue of how much omega- 6 fat should be consumed in the diet, and what the ratio of omega- 6 to omega- 3 fat should be. Numerous papers have pointed out that a high omega- 6 diet and a high omega- 6 to omega- 3 ratio are linked to heart disease, cancer, inflammatory diseases, and others (Simopoulos 2002, 2008, 2010; Lands, 2012). The AHA Science Advisory dodged both important issues and one might surmise that AHA does not want to set a limit for this fat.

However, the AHA acknowledged that other health agencies have set limits to omega- 6 in the diet (Table 1), but it defended its position of not specifying a limit by proclaiming: "The American Heart Association places primary emphasis on healthy eating patterns rather than on specific nutrient targets."

This statement is highly irresponsible: since an excess of omega- 6 fat is clearly linked to CHD, how can the AHA not issue a warning? This is also highly hypocritical and suspicious: the AHA refused to set a target for omega- 6 fat and yet aggressively set a target of $6 \%$ for saturated fat in its Presidential Advisory (Sacks et al., 2017). Why the double standard? Is the AHA protecting omega- 6 fats?

This omega- 6 fiasco will become a replay of the trans fats disaster, with soybean oil as the beneficiary. Heart disease will remain the \#1 cause of death in the US (and the world!).

\section{CANOLA OIL FOR COCONUT OIL?}

Aside from soybean oil, canola oil is the other beneficiary of the AHA warning. Since the 1990s, the agroindustry giant Calgene, which is convinced of the beneficial health properties of lauric acid, has been undertaking genetic engineering experiments on canola oil to produce a high lauric acid GMO, called Laurical 35, which contains 37\% lauric acid and $34 \%$ oleic acid (Shahidi et al., 2007). As the Canola website declared: "Domestically produced high-laurate canola oil could potentially replace some of the $\$ 400$ million of tropical oil imported annually, primarily from the Philippines, Malaysia and Indonesia" (Ag Innovation News, 2003). Thus, while the AHA warns against coconut oil, Calgene is set to enter the lauric oil market with a GM product.

\section{COCONUT OIL, SATURATED FAT, AND ANIMAL FAT: A SERIOUS MISUNDERSTANDING}

The vast majority of epidemiological studies do not distinguish between coconut oil and animal fat, and simply refer to them collectively as "saturated fat." This is a serious misunderstanding. Coconut oil is $65 \%$ medium-chain saturated fat while the different types of animal fat contain from 40 to $50 \%$ long-chain saturated fat, with the rest being monoand polyunsaturated fat. In addition, coconut oil contains from zero to $3 \mathrm{mg}$ cholesterol per $\mathrm{kg}$ (Codex, 2015), while animal fat contains various amounts of cholesterol depending on animal source (USDA, 2017). (Table 2)

Polyunsaturated fat oxidizes readily with heat and, in the presence of cholesterol, will produce oxidized cholesterol. Oxidized cholesterol has been shown to accelerate the development of atherosclerosis leading to heart disease (Staprans et al., 2000). This will not happen with coconut oil because there is only a small proportion of unsaturated fat and very little cholesterol. This is a mistake that Ancel Keys made; it is a mistake that many researchers who followed him have made. Therefore, the so-called "high quality" studies that the AHA Presidential Advisory judged as acceptable evidence against coconut oil cannot be admitted as evidence because of this fatal mistake (Sacks et al., 2017).

\section{HISTORICAL USE OF THE COCONUT}

Contrary to the claim of the AHA, there is abundant evidence to show that coconut oil and a coconut diet do not raise the incidence of heart disease and are, in fact, part of many healthy traditional diets. In the remainder of this essay, we will discuss the historical and traditional consumption of the coconut, health 
Table 2. Comparison of Fatty Acid Profile and Cholesterol Content of Coconut Oil and Various Types of Animal Fat: Butter, Beef Fat and Lard.

\begin{tabular}{|c|c|c|c|c|}
\hline \multirow[b]{2}{*}{ Fatty acid } & \multirow[b]{2}{*}{ Coconut Or'1 } & \multicolumn{3}{|c|}{ Animal fat ${ }^{2}$} \\
\hline & & Butter & $\begin{array}{l}\text { Beef fat } \\
\text { (tallow) }\end{array}$ & $\begin{array}{c}\text { Lard } \\
\text { (hog fat) }\end{array}$ \\
\hline $\begin{array}{c}\text { C4:0, } \% \\
\text { butyric acid }\end{array}$ & & 3 & & \\
\hline $\begin{array}{c}\text { C6:0, } \% \\
\text { caproic acid }\end{array}$ & 1 & 2 & & \\
\hline $\begin{array}{c}\text { C8:0, } \% \\
\text { caprytic acid }\end{array}$ & 7 & & & \\
\hline $\begin{array}{c}\text { C10:0, } \% \\
\text { capric acid }\end{array}$ & 7 & 3 & & \\
\hline $\begin{array}{c}\text { C12:0, \% } \\
\text { lauric acid }\end{array}$ & 49 & 4 & & \\
\hline $\begin{array}{c}\text { C14:0, \% } \\
\text { myristic acid }\end{array}$ & 19 & 12 & 3 & 2 \\
\hline $\begin{array}{c}\text { C16:0, } \% \\
\text { palmític acid }\end{array}$ & 9 & 26 & 27 & 27 \\
\hline $\begin{array}{c}\text { C18:0, \% } \\
\text { stearic acid }\end{array}$ & 3 & 11 & 7 & 11 \\
\hline $\begin{array}{c}\text { C16:1, } \% \\
\text { palmitoleic acid }\end{array}$ & & 3 & 11 & 4 \\
\hline $\begin{array}{l}\text { C18:1, \% } \\
\text { oleic acid }\end{array}$ & 8 & 28 & 48 & 44 \\
\hline $\begin{array}{c}\text { C18:2, \% } \\
\text { inoleic acid }\end{array}$ & 2 & 2 & 2 & 11 \\
\hline $\begin{array}{c}\text { C18:3, \% } \\
\text { Enolenic acid }\end{array}$ & 1 & & & \\
\hline $\begin{array}{c}\text { Cholesterol, } \\
\mathrm{mg} / \mathrm{kg}\end{array}$ & 0 to 3 & 2150 & 1090 & 950 \\
\hline
\end{tabular}

${ }^{1}$ Codex, 2015; ${ }^{2}$ USDA

statistics of coconut-consuming populations, and a comparison with the Western (mainly American) diet.

The coconut is one of the most ancient and widespread of edible fruits in the world (Lutz, 2011). It is part of the diet and culinary tradition of virtually all countries where the coconut grows. It is also unparalleled in its overall usefulness as a portable source of food and water and many other useful applications. The settling of the Pacific islands was made possible by the coconut (Gunn et al., 2011). This is affectionately described by Henri Hiro, indigenous advocate for the Polynesian people, in a poem which is found in the Bishop Museum in Hawaii:

\section{"Traveling companion of the Polynesians, coconut tree, indispensable support \\ For a happy and fulfilled life; coconut tree of peace, coconut tree of harmony, eternal coconut tree, with you life is there."}

Indeed, the coconut is widely revered in many cultures as the "Tree of Life."

Miguel de Loarca, a Spanish explorer in the Philippines during the 16th century, observed that "The cocoanuts furnish a nutritious food when rice is scarce" (Blair \& Robertson, 1906). It was so useful that the Spanish government in the Philippines decreed the planting of coconuts as a source of raw material and as food for the people, especially during drought.

Among some food cultures in the Pacific islands, the coconut accounts for up to $60 \%$ of fat intake. There is no report that the coconut has caused ill-health or disease, except for the occasional death from a falling coconut.

\section{HEALTH OF COCONUT-CONSUMING POPULATIONS}

Studies on the influence of dietary coconut oil on heart disease and other health factors have shown that there is no negative effect from coconut oil consumption compared with other oils and that in some cases, better health outcomes can be attributed to coconut oil.

Numerous studies have documented the absence of negative effects from coconut oil. Prior and co-workers (1981) reported that Polynesians from Pukapuka and Tokelau both consume a high saturated fat diet from coconut oil, 34\% and 63\%, respectively, and yet vascular disease was uncommon in both populations and there was no evidence of harmful effects in these populations due to their diet. A small study of 32 CHD patients and 16 matched healthy controls from the Indian state of Kerala showed that coconut and coconut oil did not play any role in the causation of CHD in this state (Kumar, 1997). A similar study conducted in West Sumatra, Indonesia, involving $93 \mathrm{CHD}$ patients with a control group showed that consumption of coconut was not a predictor for CHD (Lipoeto et al., 2004).

The association between coconut oil consumption and lipid profiles was studied in a cohort of 1,839 Filipino women (age 35-69 years) over a 22-year period, from 1983 to 2005. Lipid analysis showed that the mean TC, LDL, and triglyceride levels and TC/HDL ratio of the women were within the desirable limits set by $\mathrm{WHO}$ and that coconut oil intake may enhance HDL levels (Feranil et al., 2011).

A direct comparison between coconut oil and sunflower oil, a polyunsaturated oil, used as cooking oil was conducted to determine their effect on lipid profile, antioxidant and endothelial status in patients with stable coronary artery disease. This study was conducted for 2 years with 100 coronary artery disease patients and 100 in the healthy control group with $98 \%$ follow-up. The results showed that there was no statistically significant difference in the anthropometric, biochemical, vascular function, and cardiovascular events in both groups indicating that coconut oil does not pose any additional risk for 
heart disease compared with a polyunsaturated fat (Vijayakumar et al., 2016).

On the other hand, there are studies that show better health outcomes in populations that consume coconut oil or a coconut-based diet. In the Philippines, people from the Bicol province who have the highest consumption of coconut showed comparatively low levels of atherosclerosis and heart disease compared with people from other regions in the Philippines who consume less coconut in their diet (Florentino \& Aguinaldo, 1987).

The type of fat has a strong influence on obesity. Rural populations of Vanuatu consume fat from traditional sources, which includes coconut, while urban Vanuatu populations consume fat from imported foods, such as oil, margarine, butter, and meat. Despite the fact that rural Vanuatu populations consumed more total calories than the urban population, they had half the prevalence of obesity and diabetes (WHO, 2003).

In the US, it is interesting to note that the states with high coconut consumption - Hawaii and Florida - showed lower rates of heart disease compared to the national average in 2014 (heart disease rate per 100,000): US average (167.0); Hawaii (136.7); Florida (151.3) (KFF, 2017). Similarly, Cuba, a coconut-consuming country that has been spared the Western diet, had a mortality rate from heart disease of 144.8 from 1986 to 1997 (Cañero, 1999).

In summary, dietary studies on populations that consume coconut or coconut oil show no evidence of a higher incidence of heart disease and a number of studies report more favorable health outcomes.

\section{FROM A TRADITIONAL COCONUT DIET TO A WESTERN DIET}

A number of studies have shown that populations that shifted from a traditional coconut diet to a Western diet report poorer health status. In 1973, Ian Prior saw the unique opportunity to observe in detail a real time experiment of the effect that diet can have on Polynesians who migrated from their islands to New Zealand. He recorded mortality from heart disease, hypertensive heart disease, and blood lipids, among others. He concluded his paper with this statement: "The high price being paid by the New Zealand Maori, in terms of morbidity and mortality from a range of cardiovascular and metabolic disorders and the contrast with the picture seen among atoll dwellers, gives a clear indication of how exposure to the ways and diet of Western society can influence health and disease patterns" (Prior, 1973).
A 1999 comparative study among American and Western Samoans showed that a shift to a modern diet increased their carbohydrate and protein consumption and decreased their overall fat, in particular, saturated fat. This shift was identified as the cause of their increased incidence of obesity and cardiovascular disease (Galanis et al. 1999). WHO (2003) reported that Pacific islanders "were 2.2 times more likely to be obese and 2.4 times more likely to be diabetic if they consumed fat from imported foods rather than from traditional fat sources." Among the most commonly consumed imported fats were vegetable oil and margarine which replaced coconut oil.

\section{WILL THERE BE A SCIENCE-BASED CONCLUSION?}

In 2016, Eyres and co-workers conducted an assessment of the literature to verify the merits of the claim that coconut consumption had favorable effects on cardiovascular risk factors. After reviewing 8 clinical trials and 13 observational studies, they concluded that: "Observational evidence suggests that consumption of coconut flesh or squeezed coconut in the context of traditional dietary patterns does not lead to adverse cardiovascular outcomes." Strangely, they ended their paper with this statement: "However, due to large differences in dietary and lifestyle patterns, these findings cannot be applied to a typical Western diet" (Eyres et al., 2016).

Despite the exacting standards of science that Eyres and co-workers applied, why can't these findings be applied to a typical Western diet? The authors did not provide an explanation. With this statement, the authors have effectively put science aside.

This set of three essays has provided evidence from science and from millennia of people's experience which provide a holistic picture of the health properties of coconut oil. These essays have also pointed out specific aspects where the AHA and the Dietary Guidelines have perpetuated errors, many of which date back to the bias of Ancel Keys against saturated fat. The mistake of assuming that animal fat and coconut oil are similar means that much of the basis for the warnings against saturated fat are erroneous. In addition, recent discoveries regarding small dense $L D L$ and oxidized $L D L$ mean that conclusions from many LDL studies are questionable. Truly, wholeness leads to clarity.

These should be enough basis to reverse the AHA's campaign against coconut oil, but its real reasons may not be based on science but on its bias for a high omega- 6 diet. 


\section{REFERENCES}

Ag Innovation News, Jul-Sep 2003, Vol. 12, No. 3.

Allison DB, Egan SK, Barraj LM, Caughman C, Infante M, Heimbach JT (1999). Estimated intakes of trans fatty and other fatty acids in the US population. J Am Diet Assoc 99: 166-174.

Blair EH, Robertson JA (1906). The Philippine Islands 1493-1803. Vol 5, p 167. Translation of the writings of Miguel de Loarca (1582 - 1583).

Blasbalg TL, Hibbeln JR, Ramsden CE, Majchrzak SF, Rawlings RR (2011). Changes in consumption of omega-3 and omega- 6 fatty acids in the United States during the 20th century. Am J Clin Nutr 93: $950-62$.

[CDC] Center for Disease Control (2017). Health, United States, 2016. https://www.cdc.gov/nchs/ data/hus/hus 16.pdf\#056

Cañero AH (1999). Mortality from ischemic heart disease in Cuba. The role of diet and serum cholesterol. Revista Cubana de Cardiología y Cirugía Cardiovascular 13(1): 8-12.

[Codex] Codex Alimentarius 210-1999, amended 2015.

Dayrit F (2017a). The Warning on Saturated Fat: From Defective Experiments to Defective Guidelines.

Dayrit F (2017b). A Half-Truth is Not the Whole Truth: The AHA Position on Saturated Fat.

[EFSA] European Food Safety Authority (2009). Scientific Opinion: Labelling reference intake values for $n-3$ and $n-6$ polyunsaturated fatty acids. The EFSA Journal. 1176, 1-11.

Eyres L, Eyres MF, Chisholm A, Brown RC (2016). Coconut oil consumption and cardiovascular risk factors in humans. Nutrition Reviews 74(4): 267280.

[FAO/WHO] Interim Summary of Conclusions and Dietary Recommendations on Total Fat \& Fatty Acids, in Expert Consultation on Fats and Fatty Acids in Human Nutrition. Nov. 10-14, 2008: Geneva.

[FDA] Food and Drug Administration. Food Labeling; Trans Fatty Acids in Nutrition Labeling; Final Rule and Proposed Rule. Federal Register. July 11, 2003.
Feranil AB, Duazo PL, Kuzawa CW, Adair LS (2011). Coconut oil predicts a beneficial lipid profile in pre-menopausal women in the Philippines. Asia Pac. J. Clin. Nutr. 20(2): 190-195.

Florentino RF, Aguinaldo AR (1987). Diet and Cardiovascular Disease in the Philippines. Phil. J. Coconut Stud. 13(2): 56-70.

Galanis DJ, McGarvey ST, Quested C, Sio B, AfeleFa'Amuli S (1999). Dietary Intake of Modernizing Samoans: Implications for Risk of Cardiovascular Disease. Journal of the American Dietetic Association. 99(2): 184-190.

Gunn BF, Baudouin L, Olsen KM (2011). Independent Origins of Cultivated Coconut (Cocos nucifera L.) in the Old World Tropics. PLoS ONE 6(6): e21143.

Harris WS, Mozaffarian D, Rimm E, Kris-Etherton P, Rudel LL, Appel LJ, Engler MM, Engler MB, Sacks F (2009). Omega-6 Fatty Acids and Risk for Cardiovascular Disease. Circulation 119: 902-907.

[KFF] Kaiser Family Foundation (2017). Number of Heart Disease Deaths per 100,000 Population by Gender, Timeframe 2014. http://www.kff.org/ other/state-indicator/heart-disease-death-rate-by-ge nder/?current Timeframe $=0 \&$ sortModel $=\% 7 \mathrm{~B} \% 22$ colId\%22:\%22Location $\% 22, \% 22$ sort $\% 22: \% 22$ asc $\% 22 \% 7 \mathrm{D}$

Kumar PD (1997). The role of coconut and coconut oil in coronary heart disease in Kerala, South India. Tropical Doctor 27: 215-217.

Lands B (2012). Consequences of Essential Fatty Acids. Nutrients 4: 1338-1357;

Lipoeto NI, Agus Z, Oenzil F, Wahlqvist ML, Wattanapenpaiboon N (2004). Dietary intake and the risk of coronary heart disease among the coconut-consuming Minangkabau in West Sumatra, Indonesia. Asia Pac. J. Clin. Nutr. 13(4):377-384.

Lutz D (2011). Deep history of coconuts decoded. Washington University of St. Louis, June 24, 2011. https://source.wustl.edu/2011/06/deep-history-ofcoconuts-decoded/

Mozaffarian D, Katan MB, Ascherio A, Stampfer MJ, Willett WC (2006). Trans Fatty Acids and Cardiovascular Disease. N Engl J Med 354: 160113.

Prior I (1973). Epidemiology of cardiovascular diseases in Asian-Pacific region. Singapore Medical 
Journal 14(3): 223-227.

Prior IA, Davidson F, Salmond CE, Czochanska Z (1981). Cholesterol, coconuts, and diet on Polynesian atolls: a natural experiment: the Pukapuka and Tokelau Island studies. Am. J. Clin. Nutr. 34: 1552-1561.

[SCF] Scientific Committee on Food, Commission of the European Communities. Reports of the Scientific Committee for Food: Nutrient and energy intakes for the European Community. 1992.

Sacks FM, Lichtenstein AH, Wu JHY, Appel LJ, Creager MA, Kris-Etherton PM, Miller M, Rimm EB, Rudel LL, Robinson JG, Stone NJ, Van Horn LV (2017). Dietary Fats and Cardiovascular Disease, A Presidential Advisory from the American Heart Association. Circulation. 135: e1-e24.

Shurtleff W, Aoyagi A (2007). History of Soy Oil Hydrogenation and of Research on the Safety of Hydrogenated Vegetable Oils. (http://www. soyinfocenter.com/HSS/hydrogenation 1.php. downloaded July 3, 2017).

Shahidi F, Hamam F, Zhong Y (2007). Highlaurate canola oil in production of structured lipids. Proceedings IRC Wuhan, vol 5, p 237-238.

Simopoulos AP (2002). The importance of the ratio of omega-6/omega-3 essential fatty acids. Biomed Pharmacother 56(8): 365-79.

Simopoulos AP (2008). The Importance of the Omega-6/Omega-3 Fatty Acid Ratio in Cardiovascular Disease and Other Chronic Diseases. Exp Biol Med 233(6): 674-688.

Simopoulos AP (2010). Genetic variants in the metabolism of omega- 6 and omega- 3 fatty acids: their role in the determination of nutritional requirements and chronic disease risk. Exp Biol Med 235: 785-795.

Staprans I, Pan XM, Rapp JH, Grunfeld C, Feingold KR (2000). Oxidized Cholesterol in the Diet Accelerates the Development of Atherosclerosis in LDL Receptor- and Apolipoprotein E-Deficient Mice. Arteriosclerosis, Thrombosis, and Vascular Biology. 20: 708-714.

[USDA] United States Department of Agriculture (2017). United States Department of Agriculture. Food Composition Databases. https://ndb.nal.usda. gov/; (downloaded: May 15, 2017).
Vijayakumar M, Vasudevan DM, Sundaram KR, Krishnan S, Vaidyanathan K, Nandakumar S, Chandrasekhar R, Mathew N (2016). A randomized study of coconut oil versus sunflower oil on cardiovascular risk factors in patients with stable coronary heart disease. Ind. Heart J. 68: 498-506.

[WHO] World Health Organization (2003). Diet, food supply and obesity in the Pacific. WHO Regional Office for the Western Pacific. ISBN 92 90610441.

[WHO] World Health Organization (2015). Healthy Fact Sheet No. 394, updated Sept. 2015. (http://www.who.int/mediacentre/factsheets/fs394/ en/. downloaded March 1, 2017)

[WHO] World Health Organization (2016). Obesity and overweight. Fact sheet No. 311. (http:// www.who.int/mediacentre/factsheets/fs311/en/. downloaded July 4, 2017) 